\title{
Multiscale upwelling forcing cycles and biological response off north- central Chile
}

\author{
Ciclos multiescala en el forzamiento de la surgencia y respuesta biológica \\ en el centro-norte de Chile
}

JOSÉ RUTLLANT ${ }^{1} \&$ VIVIAN MONTECINO ${ }^{2}$

\begin{abstract}
${ }^{1}$ Departamento de Geofísica, Facultad de Ciencias Físicas y Matemáticas, Universidad de Chile, Casilla 2777, Santiago, Chile; e-mail: jrutllan@dgf.uchile.cl

${ }^{2}$ Departamento de Ciencias Ecológicas, Facultad de Ciencias, Universidad de Chile, Casilla 653, Santiago, Chile; e-mail: clorofil@uchile.cl
\end{abstract}

\begin{abstract}
The physical forcing of the upwelling along the subtropical west coasts of the continents encompasses a broad range of time scales which shape both phytoplankton biomass (Chl-a) and primary productivity (carbon fixation) changes over any given time interval. The narrow continental shelf and the steep alongshore orography off north-central Chile provide for a unique combination of year-round, upwelling-favorable winds with quasi-weekly upwelling pulses associated with atmospheric coastal-trapped disturbances (coastal lows). This variability is modulated by intraseasonal oscillations in the depth of the thermo/nutricline, produced by coastal-trapped waves in the ocean, upon which annual (seasons) and interannual (ENSO) cycles are superimposed. During coastal field experiments off Cruz Grande bay $\left(29^{\circ} \mathrm{S}\right)$, carried on in November 1987 and 1988 (opposite extremes of the ENSO cycle), mean changes of the phytoplankton-integrated Chl-a (B) and carbon fixation rate (PP) from the active to the relaxed phases of the local upwelling forcing cycle (phytopattern) were characterized. Those data were contrasted against similar ones reported off Punta Lengua de Vaca (Coquimbo, $30^{\circ} \mathrm{S}$ ) and off Mejillones peninsula (Antofagasta, $23^{\circ} \mathrm{S}$ ), encompassing different seasons and phases of intraseasonal and interannual (ENSO) cycles from 1992 to 1997. A "warm" phyto-pattern was schematically characterized by a significant increase in B and a quasi-steady evolution of PP from the active to the relaxed phases of one complete upwelling event. Conversely, relative small changes in B and a significant increase in PP characterized a "cold" phyto-pattern. It is proposed here that the ENSO "cold/warm" signal may be offset by more than one opposite "thermal" condition (seasonal and/or intraseasonal) in defining a "warm" or "cold" phyto-pattern associated with a particular cycle of the local upwelling forcing.
\end{abstract}

Key words: Chile, coastal upwelling, phytoplankton, local and remote upwelling forcing cycles, coastal-trapped waves, ENSO cycle.

\section{RESUMEN}

El forzamiento físico de la surgencia a lo largo de las costas occidentales de los continentes comprende una amplia gama de escalas temporales que configuran los cambios en la biomasa fitoplanctónica ( $\mathrm{Cl}-\mathrm{a})$ y en la productividad primaria (fijación de carbono) sobre un intervalo de tiempo cualquiera. La estrecha plataforma continental y la fuerte pendiente orográfica a lo largo de la costa en el norte y centro de Chile proporcionan una combinación única de vientos favorables a la surgencia durante todo el año con pulsos de surgencia cuasi-semanales asociados con perturbaciones atmosféricas atrapadas a la costa ("bajas costeras"). Esta variabilidad es modulada por oscilaciones intraestacionales en la profundidad de la termo/nutriclina producida por ondas oceánicas atrapadas a la costa, sobre las cuales se superponen los ciclos anuales (estaciones) e interanuales (ENOS). Durante los experimentos costeros frente a la bahía de Cruz Grande $\left(29,5^{\circ} \mathrm{S}\right.$ ) realizados en noviembre de 1987 y 1988 (extremos opuestos del ciclo ENOS), se caracterizó el cambio medio en la Cl-a (B) y en la tasa de fijación de carbono (PP) entre las fases activa y relajada del ciclo del forzamiento local de la surgencia. Esos datos fueron contrastados con otros similares reportados frente a Punta Lengua de Vaca $\left(\right.$ Coquimbo, $30^{\circ} \mathrm{S}$ ) y a la península de Mejillones (Antofagasta, $23^{\circ} \mathrm{S}$ ), que comprenden diferentes estaciones del año y diferentes fases de los ciclos intraestacionales e interanuales (ENOS) entre 1992 y 1997. Un patrón-fitoplanctónico "cálido" fue caracterizado esquemáticamente por un aumento significativo en B y por una evolución cuasi-estacionaria en PP entre las fases activa y relajada de un evento completo de surgencia. A la inversa, un patrón-fitoplanctónico "frío" se caracterizó por cambios relativamente pequeños en B y por un incremento significativo en PP. Se propone aquí que la señal "fría/cálida" del ENOS puede estar compensada por más de una condición "térmica" opuesta (estacional y/o intraestacional) en la definición de un patrón fitoplanctónico "cálido" o "frío" asociado con un ciclo particular del forzamiento local de la surgencia.

Palabras clave: Chile, surgencia costera, fitoplancton, ciclos de forzamiento local y remoto de la surgencia, ciclo ENOS. 


\section{INTRODUCTION}

Environmental variability in the ocean along the subtropical west coasts of the continents encompasses a wide range of space and time scales. In terms of primary biological production these changes modulate from hours to decades the nutrients and light supply to the upper coastal ocean. In order to assess the representativity of the scarce data sets available for any given region, physicalbiological models considering such wide range of environmental variability should be developed. A first step towards fulfilling this objective requires carefully designed field experiments in which the time-space variability of the downward solar irradiance and of the upwelling forcing mechanisms are considered together in the primary biological response, as those that had been recently undertaken off northern Chile (i.e., González et al. 1998).

Integrated studies on physical-biological aspects of the upwelling along the American and African west coasts have been performed during the 1970's, particularly through the Coastal Upwelling Ecosystem Analysis Program (CUEA: i.e., Richards 1981). Years later, the Coastal Ocean Dynamics Experiment (CODE) focused on the atmospheric and oceanic dynamics governing the wind-driven upwelling off the California coast (i.e., Beardsley et al. 1987). A comparative synthesis of the upwelling forcing mechanisms and the ocean physical and biological responses along western South America has been reviewed in Strub et al. (1998).

Based on satellite imagery, Fonseca \& Farías (1987) recognized five principal coastal upwelling areas off the Chilean coast, around which most of the primary production experiments have been performed. The Mejillones peninsula $\left(23^{\circ} \mathrm{S}\right)$ area just north of Antofagasta (Rodríguez et al. 1991, Marín \& Olivares 1999, Iriarte et al. 2000) and the Punta Lengua de Vaca $\left(30^{\circ} \mathrm{S}\right)$ area to the south of Coquimbo (Montecino et al. 1996, Torres et al. 1999, Daneri et al. 2000, Montecino \& Quiróz 2000) are particularly relevant for the present study.

Along the narrow shelf of north-central Chile, the source of the nutrient-rich water that upwells in response to the prevailing equatorward winds is associated with equatorial subsurface waters from beneath the thermocline (i.e., Marín \& Olivares 1999). Cyclic, low-frequency oscillations change the average depth of the coastal thermo/nutricline, modulating the effectiveness of the nutrient pumping into the euphotic zone during local upwelling events. These oscillatory mechanisms span from the El Niño Southern Oscillation (ENSO) cycles (interannual time scale) through seasonal to intraseasonal (IS) oscillations, the latter being mostly associated with ocean coastal-trapped waves (CTW's) of equatorial origin propagating polewards against the continental shelf (i.e., Shaffer et al. 1997).

Here, results of the coastal phytoplankton response throughout full local upwelling forcing cycles from two 10-day field campaigns at the beginning of November 1987 and 1988 off Cruz Grande Bay $\left(29.5^{\circ} \mathrm{S}\right)$ are first examined. These responses are then contrasted against similar data sets off Mejillones peninsula and off Punta Lengua de Vaca (24-30 $\mathrm{S}$, respectively).

After describing the experimental aspects of this study, results on the meteorological conditions leading to upwelling-favorable wind events

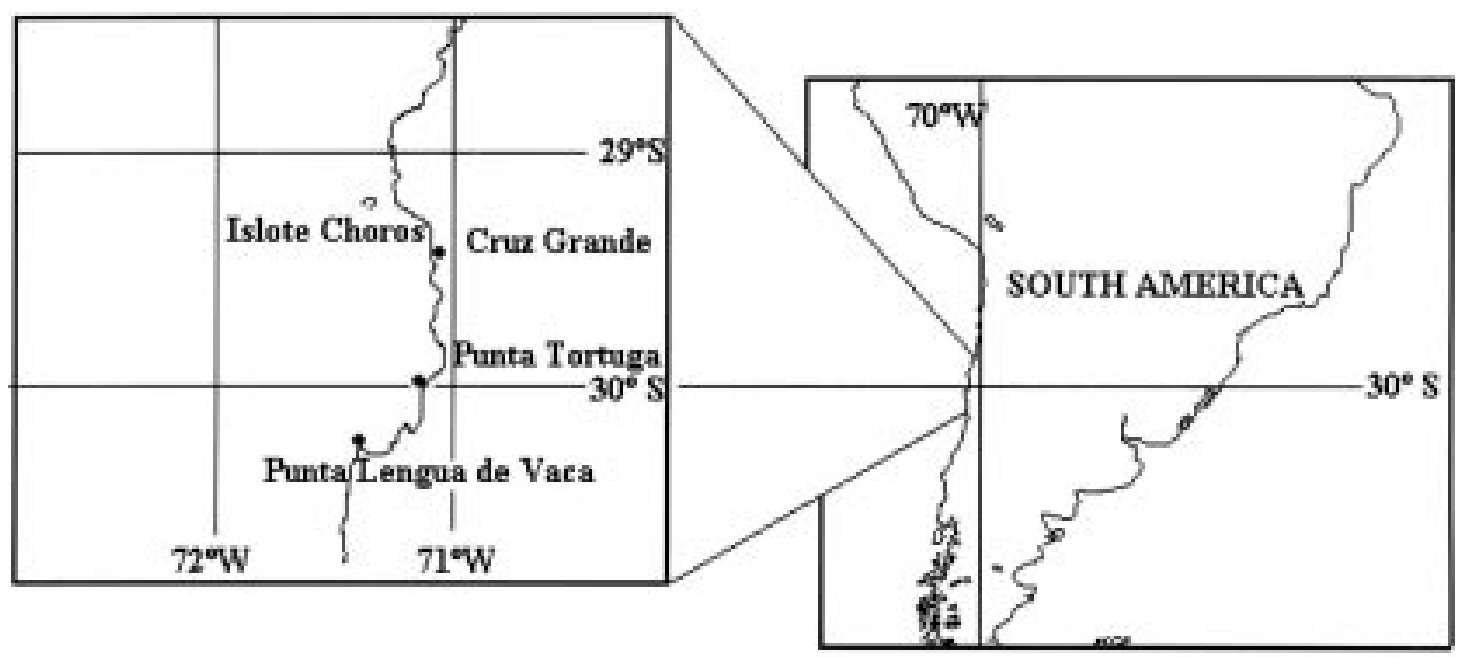

Fig. 1: Coastal area in north-central Chile around the experimental site (Cruz Grande bay), including other locations referred to in the text.

Área costera en el centro-norte de Chile en torno al sitio de los experimentos (bahía Cruz Grande), incluyendo otros lugares mencionados en el texto. 
TABLE 1

Expected thermocline/nutricline depth (THD) extremes arising from the El Niño Southern Oscillation (ENSO) cycle, the seasonal cycle and the intraseasonal cycle associated with coastally-trapped waves (CTW's) in the ocean, as represented by data (adjusted sea-level)

from tide-gauge stations

Extremos esperados en la profundidad de la termoclina/nutriclina resultantes del ciclo El Niño/Oscilación del Sur (ENOS), del ciclo anual y del ciclo intraestacional asociado con ondas atrapadas a la costa (CTW's), representado por datos (nivel del mar ajustado) de estaciones mareográficas

\begin{tabular}{lccc}
\hline & Interannual & Seasonal & Intraseasonal \\
\hline & ENSO cycle & Annual cycle & CTW’s (sea-level) \\
Minimum THD & La Niña & Early Spring & Rising \\
Maximum THD & El Niño & Late Summer & Falling \\
\hline
\end{tabular}

(UFWE's) in north-central Chile, including an UFWE climatology are presented, illustrating their seasonal frequency and intensity distributions. The upper coastal ocean response to the UFWE's experienced off Cruz Grande bay is then assessed in terms of sea-surface temperature (SST), phytoplankton chlorophyll-a biomass (B) and primary production in terms of carbon fixation rate (PP). These results are then analyzed in the context of multiscale physical forcing cycles.

A comparison of the Cruz Grande bay data with equivalent physical-biological data off Punta Lengua de Vaca and Mejillones peninsula, encompassing different seasons and phases of interannual and intraseasonal cycles from 1992 to 1997, follows next.

As a working hypothesis, the expected qualitative effects of different cycles forcing the thermocline/nutricline depth (THD) are listed in Table 1.

\section{MATERIAL AND METHODS}

The coastal area around which the air-sea interaction experiments described here were performed is depicted in Fig. 1. The principal upwelling focus in that area is located off Punta Lengua de Vaca. A secondary focus was often observed northwards of Islote Choros. The meteorological observations and the on-board and airborne measurements were performed at and off Cruz Grande bay, respectively.

${ }^{1}$ FUENZALIDA H, J RUTLLANT \& J VERGARA (1989) Meteorological aspects of water collection from stratocumuli in northern Chile. Extended Abstracts of the Third International Conference on Southern Hemisphere

Meteorology and Oceanography, Buenos Aires, Argentina, Noviembre 13-17, 1989, American Meteorological Society: 156-161.
Two field campaigns were carried out between November 2-11, 1987, and between November 34,1988 . The meteorological component of the study was performed jointly with the Camanchaca Project (Fuenzalida et al. 1989) ${ }^{1}$. Atmospheric sea-level pressure (SLP), cloud cover, wind speed and wind direction data reported every $3 \mathrm{~h}$ at Punta Tortuga $\left(30^{\circ} \mathrm{S}\right)$ were analyzed. Surface meteorological data at the experimental site were obtained with a portable Climatronics automatic weather station located at Cruz Grande in 1987 and at Islote Choros (Fig. 1) in 1988. Background synoptic meteorological conditions were assessed through surface charts from the NCEP-NCAR Reanalysis Program (Kalnay et al. 1996).

A daily coastal upwelling index based on the nature of the coastal wind regime was defined considering the changes in the nocturnal phase of the wind regime that take place within the $50-\mathrm{km}$ average offshore extension of the coastal strip influenced by cold water upwelling in northern Chile (Yáñez et al. 1995). At the coast the prevailing southwesterly winds (upwelling-favorable) blow steadily in the afternoon and evening attaining its maximum strength around 17:0018:00 h. At dawn and early morning coastal winds usually vanish, reflecting the nocturnal land cooling. Off the coast this strong coastal diurnal cycle in the winds fades away, being almost negligible at about $12 \mathrm{~km}$ offshore (i.e., Beardsley et al. 1987 for the coast of California) where the equatorward winds blow without interruption during an upwelling-favorable wind event. Therefore, while during the afternoon and evening upwelling progresses mainly due to the Ekman offshore drift, at nighttime and early morning upwelling still goes on due to the cyclonic alongshore wind-stress curl (Ekman pumping). Since in both cases the upwelling strength is proportional to the afternoon wind speed at the coast, an average alongshore pseudo wind stress (AWS) 
between 12:00 and 24:00 h (local time) was proposed (Rutllant 1993) ${ }^{2}$, and will be used here as a daily coastal upwelling index.

Quality-controlled sea level data for both study periods (1987 and 1988) were obtained from tide gauges at Caldera $\left(27^{\circ} \mathrm{S}\right)$ and Valparaíso $\left(33^{\circ} \mathrm{S}\right)$ kept by the TOGA Sea Level Center at the University of Hawaii.

A small twin-engine airplane was flown twicea-day following a $50 \mathrm{~km}$ cross-shore track to measure the sea-surface temperature (SST) by means of a Barnes -5 radiation thermometer. High resolution SST fields through NOAA-AVHRR images at 09:00, 16:00, 18:00 and 21:00 h were kindly provided by Martín Farías at the Center for Space Studies, Universidad de Chile.

On-board measurements were performed at the $15 \mathrm{~m}$ long R/V Stella Maris II in westward transects off Cruz Grande bay. Oceanographic stations at 2, 4, 8, 12, 20 and 24 nautical miles (nmi) off the coast were occupied for water column sampling. Every other day, only surface water samples for chlorophyll-a (Chl-a) concentration measurements were collected. A description of the physical oceanography conditions during those cruises was presented in Moraga (1996).

For phytoplankton counts, Chl-a and primary productivity $\left({ }^{14}\right.$ Carbon fixation) measurements, additional water samples were obtained within an euphotic zone (Zeu) defined as the $1 \%$ lightpenetration depth. Radiation measurements (PAR) were obtained by means of a 192 SB quantummeter (LiCor, USA). Primary productivity experiments were conducted every other day from a boat close to the Cruz Grande dock with the samples of the preceding day, maintained in dark conditions in a portable cooler $\left(10^{\circ} \mathrm{C}\right)$. Two clear and one dark $100 \mathrm{ml}$ bottles with water samples were inoculated with $5 \mu \mathrm{Ci}$ of $\mathrm{NaH}^{14} \mathrm{CO}_{3}$ and incubated in situ for 3 to $4 \mathrm{~h}$ around noon at five depths (Margalef \& Vives 1967, Strickland \& Parsons 1968) with standard light percentages $(100,75,50,25$ and $1 \%)$ and equivalent to those measured at the corresponding sampling levels (Kirk 1995, Montecino \& Pizarro 1995). After filtration $(0.45 \mu \mathrm{m}$ membrane filters $)$ the filters were poured into vials with dioxane scintillation cocktail (Shindler 1966) for subsequent counting. For carbon fixation calculations, a constant value of $22,000 \mathrm{mg} \mathrm{C} \mathrm{m}^{-3}$ of inorganic carbon was

${ }^{2}$ RUTLLANT J (1993) Coastal lows and associated southerly wind events in north-central Chile. Preprints of the IV International Conference on Southern Hemisphere Meteorology and Oceanography. Hobart, Australia, 29 March-2 April 1993, American Meteorological Society: 268-269. used and the result from dark bottles was substracted from the average of the clear ones (Montecino et al. 1996). For Chl-a measurements, two-liter water samples were filtered through glass-fiber filters (Millipore) and kept refrigerated until further acetone extraction and spectralphotometry readings. Chl-a and net carbon fixation results were integrated in Zeu. Also at each depth the net carbon fixation was standardized by Chl-a to account for the maximum specific primary production.

RESULTS

The November 1987 and 1988 air-sea interaction experiments off Cruz Grande bay

Local forcing of the upwelling. Time series of the daily average surface pseudo-stress of the alongshore wind component from noon to midnight (AWS), derived from winds recorded at Punta Tortuga for the 1987 and 1988 campaigns (Fig. 2 ), indicate an UFWE on November 4 and 5, 1987. After a secondary increase in the AWS on November 7 , the subsequent relaxation culminated on November 11 with a wind reversal.

In November 1988 the first 10 days coincided with a long relaxation period following an UFWE on October 30-31, with a minor event on November 5 and a moderate one on November 10-11.

Sea-level pressures (SLP's) during the 1987 and 1988 campaigns (Fig. 2) indicate that upwelling-favorable winds in 1987 occurred while daily SLP's were decreasing, as previously established for north-central Chile (Rutllant 1993, 1994). Wind relaxations were mostly associated with stationary or increasing SLP's. Cloud-cover changes from clear skies during active upwelling to overcast during relaxation were also consistent with previous studies (Rutllant 1994).

The principal UFWE between November 4-6, 1987 was associated with the post-frontal strengthening of the subtropical anticyclone (November 4 and 5 ) followed by a coastal low setting in on November 5 and 6 coinciding with the maximum AWS in the study area. The southwesterly winds relaxed on November 9, when the center of the low reached the study area. The synoptic weather conditions on November 6 (Fig. 3A) depict a coastal trough between the subtropical anticyclone to the west and a migratory high over northeastern Argentina.

In November 1988, the UFWE event ahead of the field work occurred in connection with a coastal low that culminated between October 31 and November 1. A weak front reached the study 

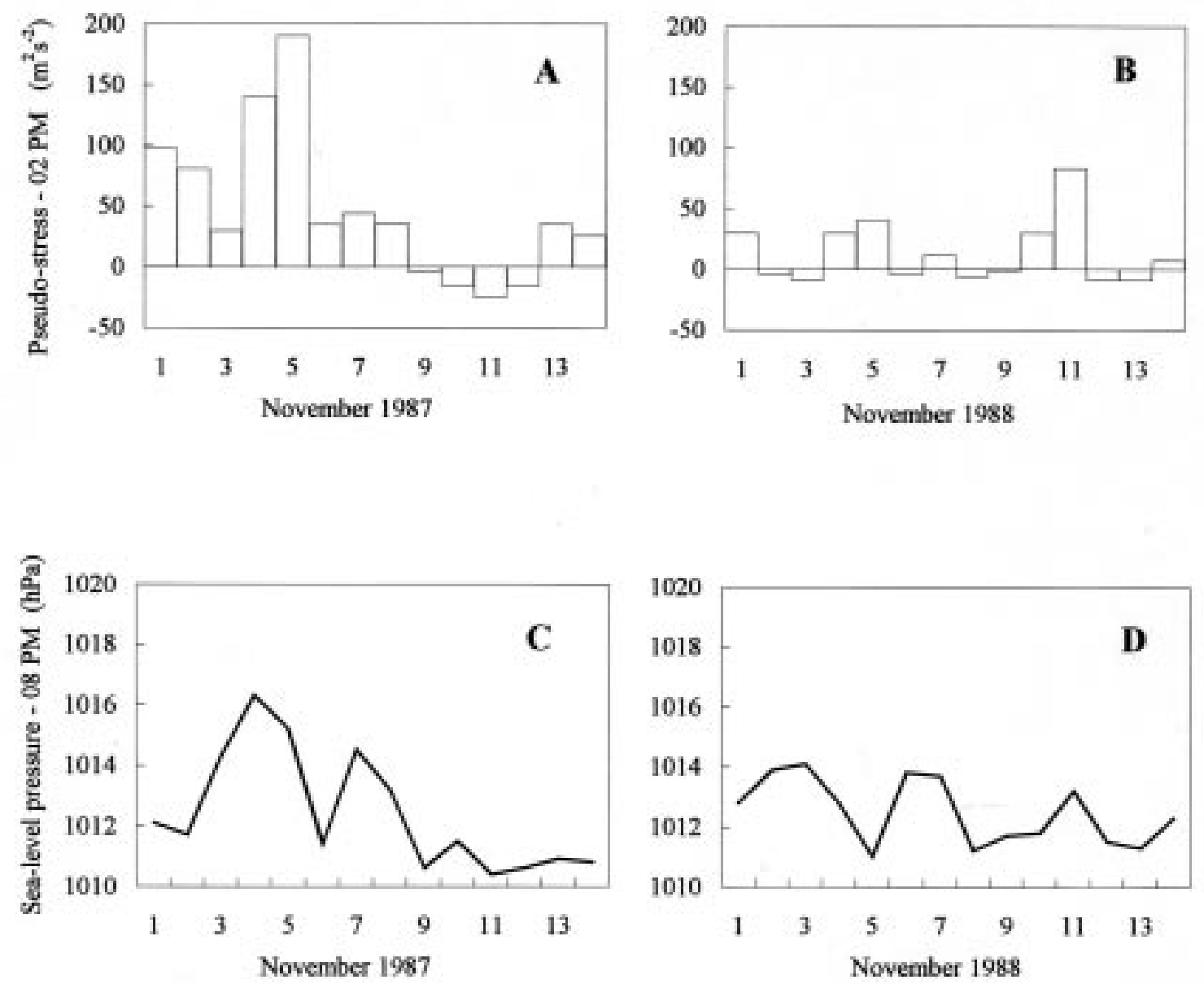

Fig. 2: Time series of (A, B) daily alongshore pseudo-windstress (AWS) in $\left(\mathrm{m}^{2} \mathrm{~s}^{-2}\right)$ and (C, D) atmospheric sea-level pressure (SLP) in (hPa) at Punta Tortuga $\left(30^{\circ} \mathrm{S}\right)$ during the November 1987 and November 1988 campaigns.

Series temporales del (A, B) seudo-esfuerzo del viento diario a lo largo de la costa (AWS) en $\left(\mathrm{m}^{2} \mathrm{~s}^{-2}\right)$ y de (C, D) la presión atmosférica a nivel del mar (SLP) en (hPa) en Punta Tortuga (30 S) durante las campañas de noviembre de 1987 y noviembre de 1988 .

area on November 9, resulting in the moderate UFWE that started on November 10 and lasted until November 11. The NCEP/NCAR weather pattern for November 12 is illustrated in Fig 3B, revealing marked similarities with Fig. $3 \mathrm{~A}$.

In order to establish a possible seasonal dependence of the recurrence and duration of strong UFWE's, results from 28 years (1958-1985) of radiosonde observations at Quintero $\left(33^{\circ} \mathrm{S}\right)$ are described in Table 2. Seasonal averages (V) and standard deviations $(\sigma)$ of the daily alongshore wind components (positive equatorwards), near the time of the wind maxima $(20: 00 \mathrm{~h})$ at 1,000 $\mathrm{hPa}(\mathrm{V})$, were calculated to normalize departures during UFWE's. The 1,000 hPa standard pressure level, equivalent to an average altitude of about $200 \mathrm{~m}$, was selected to remove surface local influences. Statistical results reveal that upwelling- favorable winds are stronger in the austral summer followed by the austral spring, with standard deviations of 1.13 and $1.41 \mathrm{~m} \mathrm{~s}^{-1}$ over the corresponding averages, respectively. About 1 out of 6 days in all seasons experienced alongshore speeds that exceed one standard deviation over the corresponding average, with a similar (weekly) periodicity. Strong UFWE's, considered here as those with two or more consecutive days in which the speed exceeds one standard deviation, are represented by the seasonal average occurrences lasting 2, 3, 4 and 5 days (Table 2). The seasonality of those UFWE's is fairly homogeneous, although late-spring and early-summer tend to concentrate the occurrence of longer events. Typical return periods are about 40 days for 2-day UFWE's and about once per season for 3-day UFWE's. 
Seasonal averages $(\mathbf{V})$ and standard deviations $(\sigma)$ of the daily alongshore wind components $(\mathrm{V})$ at 20:00 $\mathrm{h}$ for the 1,000 hPa pressure level at Quintero (1958-1985). Days = number of days per season in which $\mathrm{V}>\mathbf{V}+\sigma: 2,3,4$ and 5 indicate the number of consecutive days fulfilling $\mathrm{V}>\mathrm{V}+\sigma$

Promedios estacionales (V) y desviaciones típicas (s) de la componente del viento paralela a la costa (V) a las 20:00 h para el nivel de presión de $1.000 \mathrm{hPa}$ en Quintero (1958-1985). Days = número de días en cada estación del año en que $\mathrm{V}>\mathbf{V}+\sigma: 2,3,4$ y 5 indican el número de días consecutivos en los que se cumple $\mathrm{V}>\mathbf{V}+\sigma$

\begin{tabular}{lcccccccc}
\hline Season & $\begin{array}{c}\mathbf{V} \\
\left(\mathrm{m} \mathrm{s}^{-1}\right)\end{array}$ & $\begin{array}{c}\mathbf{V}+\sigma \\
\left(\mathrm{m} \mathrm{s}^{-1}\right)\end{array}$ & $\boldsymbol{\sigma} / \mathbf{V}$ & $\begin{array}{c}\text { Days } \\
\mathbf{V}>\mathbf{V}+\sigma\end{array}$ & 2 & 3 & 4 & 5 \\
\hline DJF & 3.0 & 6.4 & 1.13 & 15.4 & 2.1 & 0.9 & 0.2 & 0.2 \\
MAM & 1.4 & 4.9 & 2.50 & 12.8 & 1.8 & 0.6 & 0.3 & 0.1 \\
JJA & 0.7 & 5.1 & 6.29 & 13.9 & 1.9 & 0.8 & 0.2 & 0.1 \\
SON & 2.7 & 6.5 & 1,41 & 15.5 & 2.7 & 0.7 & 0.3 & 0.1 \\
\hline
\end{tabular}

Ocean conditions. The low-frequency fluctuations of the adjusted sea-level (ASL) at Caldera $\left(27^{\circ} \mathrm{S}\right)$ and Valparaíso $\left(33^{\circ} \mathrm{S}\right)$ for the austral springs of 1987 and 1988 (Fig. 4) indicate rising ASL during the first campaign (1987) and stationary ASL during the second one (1988). As illustrated in Shaffer et al. (1997), intraseasonal (30 to 60 days) fluctuations of equatorial origin are particularly energetic off north-central Chile during the austral summers of El Niño. They propagate poleward along the South American coast as coastal-trapped waves (CTW's).

As shown by Hormazabal et al. (2001) and observed in Vega et al. (2000) ${ }^{3}$, colder periods (shallow thermocline) lag by around 12 days (about 90 degrees of phase lag) the minimum (lower ASL) in the ASL intraseasonal signal. Therefore, rising intraseasonal sea-level conditions (coldest SST's) indicate shoaling of the thermo/nutricline close to the coast. Under those
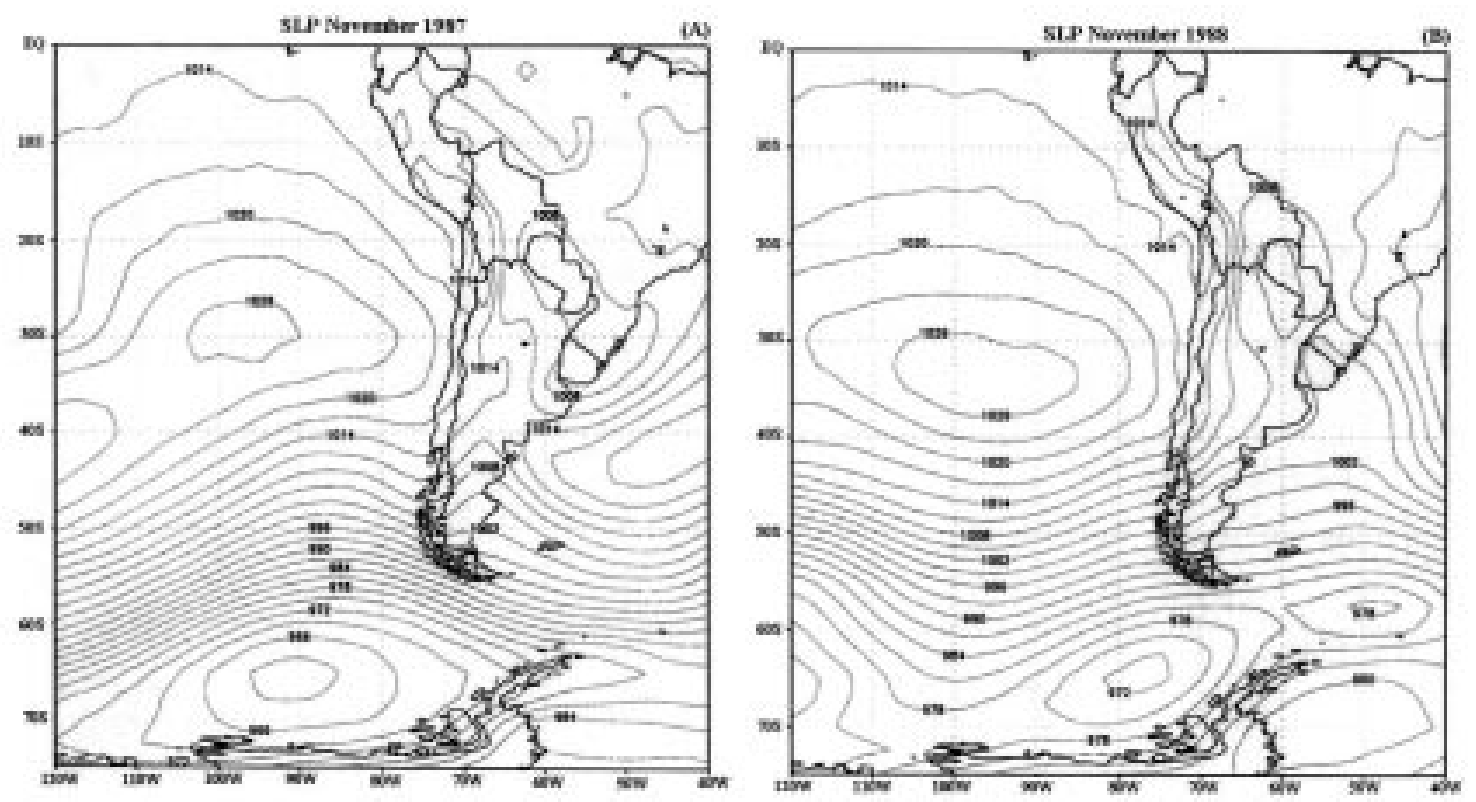

Fig. 3: Synoptic weather conditions on (A) November 6, 1987 and (B) November 12, 1988 from the NCEP/NCAR Reanalysis Project (Kalnay et al. 1996) highlighting a coastal trough between the subtropical anticyclone to the west and a migratory high over northwestern Argentina.

Condiciones sinópticas del tiempo para (A) 6 de noviembre de 1987 y (B) 12 de noviembre de 1988 tomadas del Programa de Reanálisis del NCEP/NCAR (Kalnay et al. 1996) destacándose una vaguada costera entre el anticiclón subtropical al oeste y una alta migratoria sobre el noroeste argentino. 
circumstances upwelling favorable winds can efficiently pump up cold, nutrient rich water into the coastal euphotic zone. The strong UFWE during the 1987 experiment off Cruz Grande bay developed within relatively warm oceanic waters, consistent with the El Niño condition. However, the rising ASL (intraseasonal remote upwelling forcing) illustrated in Fig. 4 was associated with a narrow coastal cold-water plume. In fact, this cold-water plume, already present on November 4 to the west of Punta Lengua de Vaca, began its northward expansion on November 5, reaching the latitude $29^{\circ} 30^{\prime}$ S on November 6 (Fig. 5). The wind relaxation that occurred immediately thereafter coincided with the onset of the coastal stratus clouds. Just after the peak of the event, on November 6 the maximum zonal SST gradient (upwelling front) was located at about $45 \mathrm{~km}$ off Cruz Grande (Fig. 5).

In 1988 comparatively colder oceanic waters prevailed, consistent with La Niña large-scale conditions. In that case it was impossible to follow the evolution of the upwelled waters observed on October 30 and 31 because of the overcast conditions present between November 1 and 11. From the satellite SST image on October 31 (not shown here) the upwelling front could be located around $80 \mathrm{~km}$ off Cruz Grande.

SST-time sections along the $50 \mathrm{~km}$ offshore flight tracks for November 1987 (09:00 h) and November 1988 (15:00 h) are illustrated in Fig. 6. While offshore conditions reflect the warm/cold waters associated with El Niño/La Niña largescale conditions, in both campaigns near-shore SST's changed from colder conditions during the active upwelling phase, to warmer values during the relaxed upwelling phase.

Consistent with the described SST space-time patterns and the rising ASL, averages in the upper $75 \mathrm{~m}$ showed an increase in salinity and a decrease in temperature from November 2-8, 1987 (Moraga 1996). During the 1988 experiment, subsurface temperatures down to $50 \mathrm{~m}$ depth, measured with a thermistor chain (Moraga 1996), indicated minimum temperatures on the $11^{\text {th }}$ and $12^{\text {th }}$, consistent with the mild UFWE on the $10^{\text {th }}$ to $11^{\text {th }}$ that followed the long relaxation period.

Phytoplankton-patterns. From the active phase of the upwelling to the onset of relaxation be-

${ }^{3}$ VEGA S, J RUTLLANT \& I MASOTTI (2000) Local and remote forcing of coastal upwelling near Valparaíso, Chile $\left(33^{\circ} \mathrm{S}\right)$ in late springs of 1996 (La Niña) and 1997 (El Niño). Preprints Seventh International Conference on Southern Hemisphere Meteorology and Oceanography, Santiago, Chile, 3-7 April 2000, American Meteorological Society: 39-40.
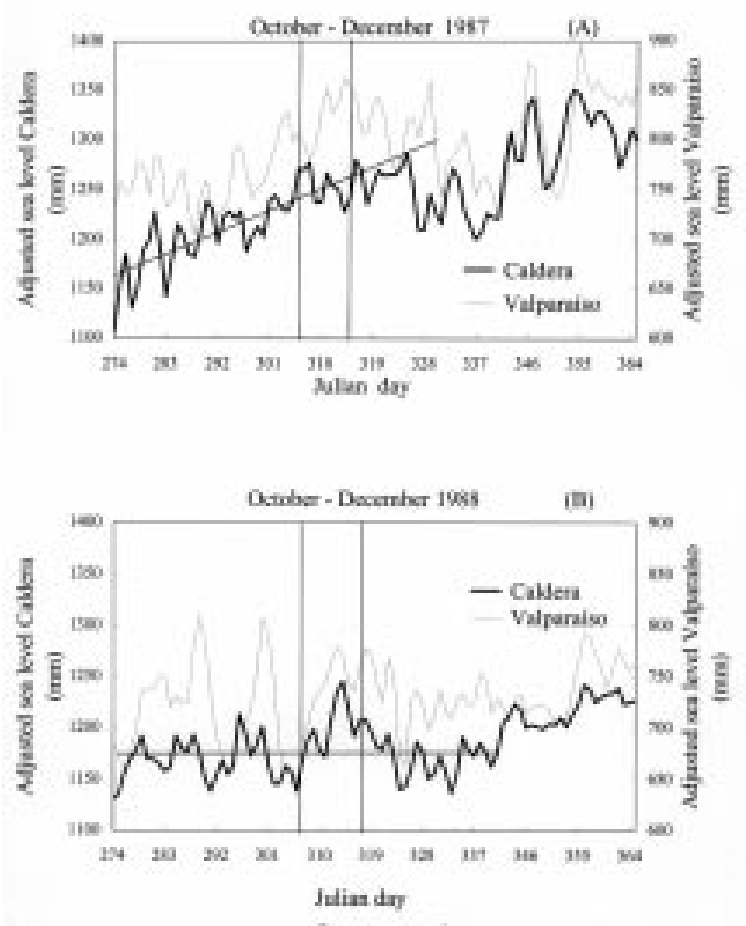

Fig. 4: Time series of adjusted sea-level (ASL) for Caldera $\left(27^{\circ} \mathrm{S}\right)$ and Valparaíso $\left(33^{\circ} \mathrm{S}\right)$ during the austral springs of (A) 1987 and (B) 1988 (Julian days). Campaign periods are indicated between vertical lines.

Series de tiempo del nivel de mar (ASL) en Caldera $\left(27^{\circ} \mathrm{S}\right)$ y Valparaíso $\left(33^{\circ} \mathrm{S}\right)$ durante las primaveras australes de $(\mathrm{A})$ 1987 y (B) 1988 (días Julianos). Los períodos de medición están indicados entre barras verticales.

tween November 4-6, 1987, mean values of Zeuintegrated Chl-a (B) increased steadily from less than 35 up to more than $100 \mathrm{mg} \mathrm{Chl-a} \mathrm{m}^{-2}$, staying at this level throughout the relaxation phase. During the 1988 experiment, from the relaxation to the following active phase of the upwelling cycle (reverse sequence), the corresponding mean $B$ values decreased slightly from above 70 down to ca. $30 \mathrm{mg}$ Chl-a $\mathrm{m}^{-2}$. For every day single B values as a function of the offshore distance (nmi) for November 1987 and November 1988 are presented in Table 3. Euphotic depths changed accordingly in both field experiments, with PAR extinction coefficients ranging from -0.09 and $-0.38 \mathrm{~m}^{-1}$. The average euphotic zone was less than $50 \mathrm{~m}$ and stayed always within the surface mixed layer, as determined in Moraga (1996). A significant negative linear correlation between the depth of Zeu and the mean Chl-a concentration was obtained $(\mathrm{r}=-0.73, \mathrm{n}=28)$, considering observations for both years. Results from the seven carbon fixation experiments performed in each period indicate surface values ranging from 0.03 to $13.3 \mathrm{mg} \mathrm{C} \mathrm{m}^{-3} \mathrm{~h}^{-1}$ in 1987 and from 0.6 to 


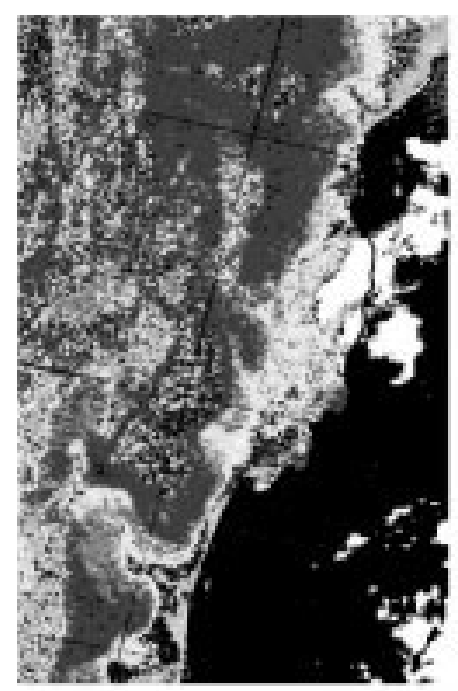

4 November 1987

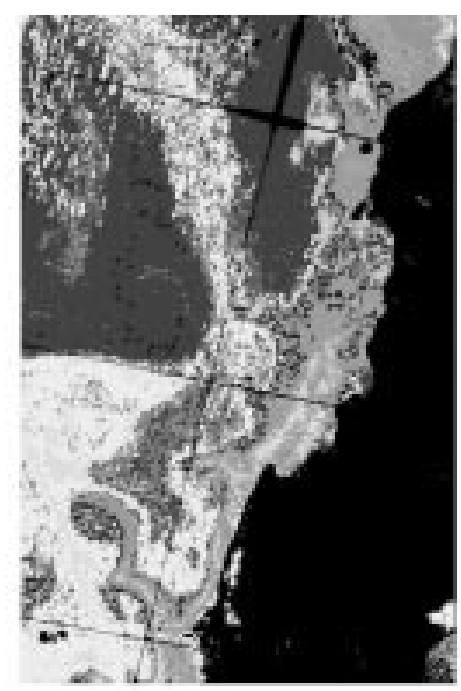

5 November 1987

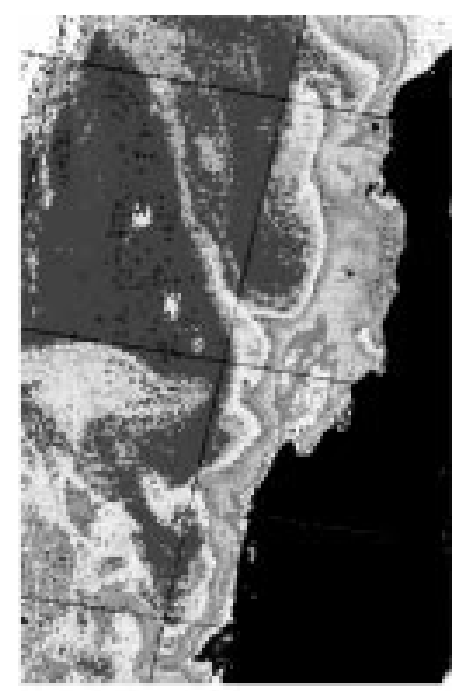

6 November 1987

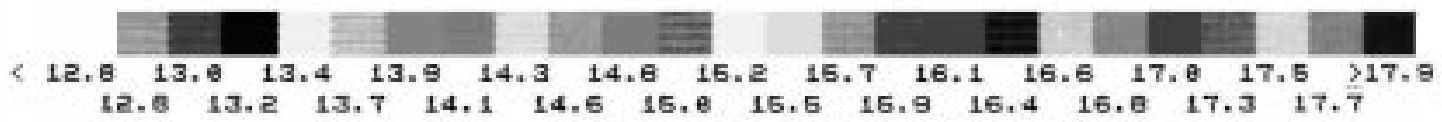

Fig. 5: SST fields in the study area for November 4, 5 and 6, 1987, showing the evolution of the upwelling plume. NOAA/AVHRR data obtained from the Center for Space Studies at the Universidad de Chile.

Campos de TSM en el área de estudio para el 4, 5 y 6 de noviembre de 1987, donde aparece la evolución del penacho de surgencia. Datos del sensor NOAA/AVHRR obtenidos por el Centro de Estudios Espaciales de la Universidad de Chile.

$9.4 \mathrm{mg} \mathrm{C} \mathrm{m}{ }^{-3} \mathrm{~h}^{-1}$ in 1988. Maximum specific primary productivity in the water column $\left(\mathrm{PB}_{\max }\right)$, expressed in $\mathrm{mg}$ of carbon per $\mathrm{mg}$ of Chl-a per hour, fluctuated between 0.8 and 6.0 in 1987 and from 1.8 and 5.0 in 1988 (Table 3 ). In addition to these maximum rate values for given stations and days, Zeu-integrated primary productivities (PP) averaged over the whole transect for each day are also indicated in Table 3 .

The biological response (phyto-pattern) for both field experiments can be characterized as follows: during the warm phase of the ENSO cycle in November 1987 (late spring: warm) with a slowly rising sea-level (cold), B increased more than three times from the active to the relaxed phase of the local wind forcing, with a slight decrease in PP (Table 3 and 5).

Conversely in November 1988 (late spring: warm), during La Niña (cold) phase of the ENSO cycle, the sea level was intraseasonally steady (only high frequency variability). In this case, while B increased moderately, PP increased by almost a factor of three from the active to the previous relaxed phase (reversed sequence) of the local wind forcing (Table 3 and 5).
Multiscale upwelling forcing and phytoplanktonpatterns off north-central Chile

In order to see how the 1987-1988 multiscale environmental variability and the corresponding $\mathrm{B}$ and $\mathrm{PP}$ responses (phyto-patterns) off Cruz Grande Bay fit into a more general picture along the coast of north-central Chile, equivalent published and unpublished data for the 1992-1997 JGOFS-CHILE cruises off Punta Lengua de Vaca $\left(30^{\circ} \mathrm{S}\right)$ (Montecino et al. 1996, Montecino \& Quiróz 2000) and for the 1997-1998 SECTORIAL cruises off Mejillones Peninsula (23 $\mathrm{S}$ ) (González et al. 1998, Rutllant et al. 1998, Iriarte et al. 2000, Pizarro et al. 2002) have been analyzed.

First, the interannual scale of variability has been represented by the warm (W, El Niño) and cold (C, La Niña) extremes of the ENSO cycle, following Trenberth (1997). A transition phase (T) has also been considered for those months not included as W or C in Trenberth's classification. The seasonal cycle has been divided into quarterly periods, JFMA ( $\mathrm{SU}=$ austral summer), MJJA (WI = austral winter) and SOND (SP = austral spring). 
Intraseasonal (IS) variability has been represented through IS cyclic changes in adjusted sealevel (ASL) at Caldera $\left(27^{\circ} \mathrm{S}\right)$. Here three ASL categories are considered: Rising (R), Falling (F) and Stationary (S).

The shortest or event-scale variability (3 to 7 days), resulting from pulses of the prevailing alongshore equatorward winds, considers two phases: active (AT) and relaxed (RX) according to the upwelling conditions represented by the daily coastal upwelling index (AWS values).

Results of the distribution of $\mathrm{B}$ and $\mathrm{PP}$ are presented in Table 4. Given the scarcity of observational data, its broad range in space variability and its subsequent distribution into the several scales of time variability analyzed here, formal statistical analysis was not intended. However, trend patterns represented in Table 5 seem to be consistent. In fact, the late-spring (warm) phytopattern response with rising sea level (cold) during El Niño (warm) at Cruz Grande bay (November 1987) is similar ("warm type") to those in early-summer (warm), stationary sea-level conditions during the milder El Niño's (warm) in January 1994 and 1995 at Punta Lengua de Vaca. The opposite ("cold type") phyto-pattern response through the local forcing cycle observed at Cruz Grande in the late-spring (warm) of 1988 with La Niña (cold) and stationary sea-level, is similar to those observed off Mejillones Peninsula in July (winter: cold) 1997 with rising sea-level (cold), in spite of the El Niño (warm) conditions.

From this characterization it may be proposed that the ENSO signal, determining the average

TABLE 3

Euphotic zone (Zeu), Zeu-integrated chlorophyll a (Chl-a) and maximum Chl-a specific primary productivity $\left(\mathrm{PB}_{\max }\right.$ ) at different offshore distances during November 1987 and November 1988 off Cruz Grande Bay. The mean daily Zeu-integrated primary productivity (PP) are shown in the last column

Zona eufótica (Zeu), clorofila-a integrada (Chl-a) en Zeu y productividad primaria específica máxima (PB ${ }_{\text {max }}$ a diferentes distancias de la costa en noviembre de 1987 y noviembre de 1988 frente a bahía Cruz Grande. Los promedios por día de productividad primaria integrada en Zeu (PP) se muestran en la última columna

\begin{tabular}{|c|c|c|c|c|c|}
\hline Date & $\begin{array}{l}\text { Offshore distance } \\
\text { (nmi) }\end{array}$ & $\begin{array}{l}\text { Zeu } \\
(\mathrm{m})\end{array}$ & $\begin{array}{l}\text { Integrated Chl-a } \\
\qquad\left(\mathrm{mg} \mathrm{m}^{-2}\right)\end{array}$ & $\begin{array}{c}\mathrm{PB}_{\max } \\
\left(\mathrm{mgC}_{\left.\mathrm{mg} \mathrm{Chl}-\mathrm{a} \mathrm{h}^{-1}\right)}\right.\end{array}$ & $\begin{array}{c}\text { mean PP } \\
\left(\mathrm{mgC} \mathrm{m}^{-2} \mathrm{~d}^{-1}\right)\end{array}$ \\
\hline \multirow[t]{3}{*}{ 2/11/1987 } & 2 & 47 & 43.0 & 4.1 & 620 \\
\hline & 8 & 29 & 13.2 & 6.0 & \\
\hline & 12 & 43 & 39.3 & & \\
\hline \multirow[t]{2}{*}{ 4/11/1987 } & 4 & 14 & 50.2 & & \\
\hline & 20 & 27 & 16.9 & 5.4 & \\
\hline \multirow[t]{3}{*}{$6 / 11 / 1987$} & 4 & 17 & 128.0 & 1.0 & 482 \\
\hline & 8 & 26 & 77.0 & & \\
\hline & 12 & 23 & 106.8 & 1.0 & \\
\hline \multirow[t]{3}{*}{$8 / 11 / 1987$} & 4 & 14 & 109.3 & 1.2 & 397 \\
\hline & 8 & 22 & 127.8 & & \\
\hline & 20 & 17 & 82.5 & 0.8 & \\
\hline \multirow[t]{3}{*}{ 10/11/1987 } & 4 & 12 & 101.9 & & \\
\hline & 8 & 33 & 47.2 & & \\
\hline & 20 & 19 & 186.3 & & \\
\hline \multirow[t]{4}{*}{ 5/11/1988 } & 4 & 5 & 49.1 & & 922 \\
\hline & 8 & 19 & 117.4 & & \\
\hline & 12 & 22 & 73.4 & & \\
\hline & 24 & 18 & 69.1 & 2.7 & \\
\hline \multirow[t]{4}{*}{ 7/11/1988 } & 4 & 12 & 24.9 & & 667 \\
\hline & 8 & 16 & 74.0 & & \\
\hline & 12 & 24 & 41.8 & 5.0 & \\
\hline & 24 & 17 & 91.3 & 1.1 & \\
\hline \multirow[t]{4}{*}{ 9/11/1988 } & 4 & - & 26.7 & & 428 \\
\hline & 8 & 19 & 58.8 & & \\
\hline & 12 & 42 & 33.2 & 4.5 & \\
\hline & 24 & 47 & 45.1 & 1.8 & \\
\hline \multirow[t]{4}{*}{$11 / 11 / 1988$} & 4 & 28 & 11.9 & & 222 \\
\hline & 8 & - & 12.1 & & 222 \\
\hline & $\begin{array}{r}0 \\
12\end{array}$ & 43 & 34.7 & 1.8 & \\
\hline & 24 & 39 & 37.2 & 1.0 & \\
\hline
\end{tabular}


depth of the thermo-nutricline, may be balanced by more than one opposite thermal condition (seasonal and intraseasonal) in defining a "warm" or "cold" phyto-pattern.

\section{DISCUSSION}

Upwelling-favorable wind events observed during and around the 1987 and 1988 air-sea interaction experiments were associated with a strengthening of the zonal pressure gradients between the passage of a frontal perturbation and the onset of a coastal low. The southward propagation of the coastal low generates a strong and rapidly changing meridional pressure gradient, leading to an ageostrophic wind component along the coast. This results in the strengthening of the upwelling- favorable winds before the passage of the center of the low (Rutllant 1994).

During the active phase of the upwelling downslope air subsidence associated with the leading sector of the coastal low produces clear skies (Rutllant 1981). Conversely, the wind relaxation and the frequent wind reversals immediately after the culmination of the low are associated with a sign change in the meridional pressure gradient, favoring the inland penetration of coastal stratus clouds.

Differences in the climate characteristics between 1987 and 1988 field experiments, consistent with the corresponding phases of the ENSO cycle, may explain differences in the local forcing cycles. In fact, the spring of 1987 was rainier than average in central Chile because of persistent blocking of the mid-latitude westerly flow. As discussed in Rutllant \& Fuenzalida (1991) that

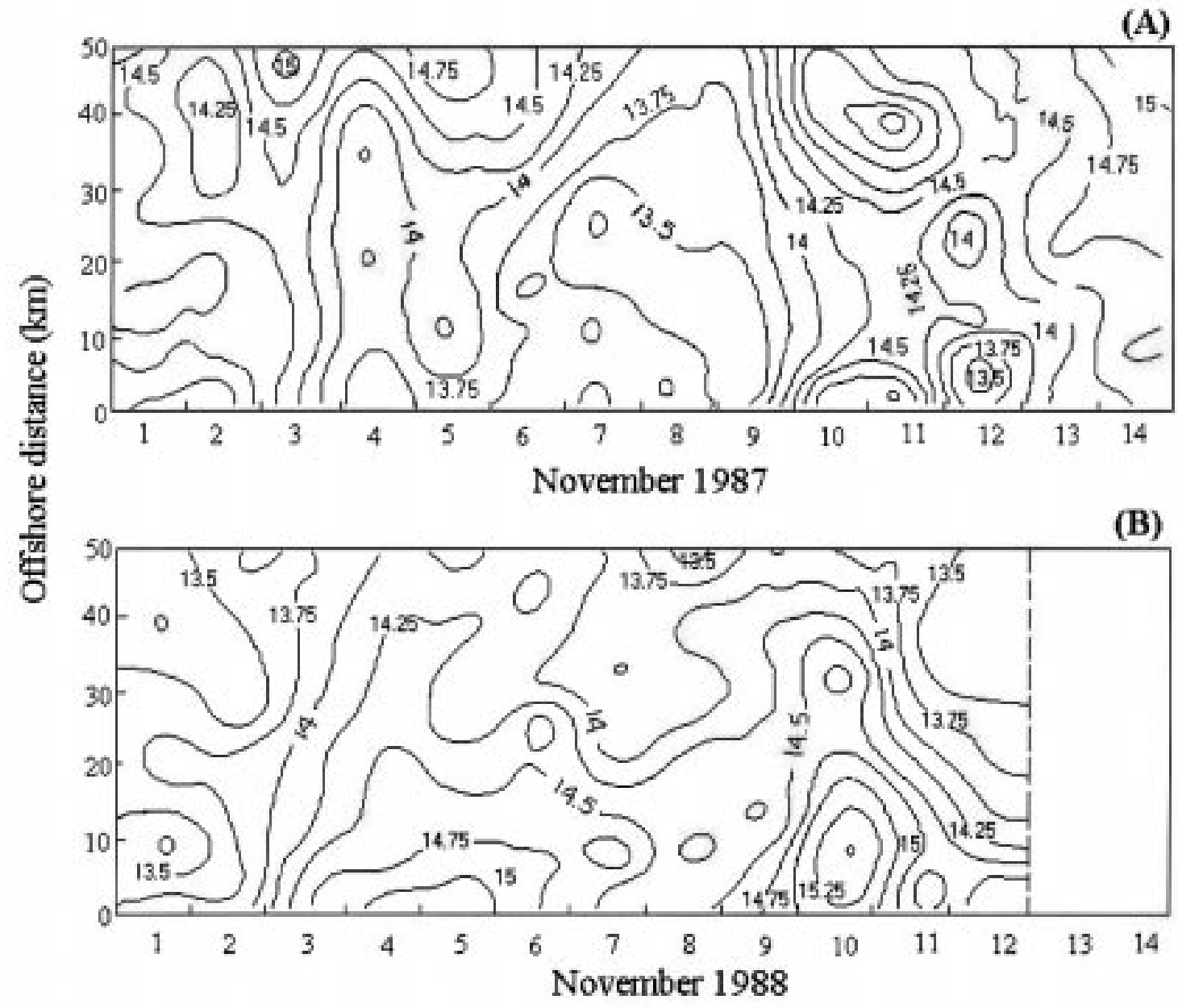

Fig. 6: Time-offshore distance SST cross-sections derived from airborne (PRT) measurements: (A) 09:00 h flights for November 1987; (B) 15:00 h flights for November 1988. (adapted from Fuenzalida et al. 1989). ${ }^{1}$

Secciones tiempo-distancia costa afuera de la TSM derivada de mediciones aéreas (PRT): (A) vuelos de las 09:00 h para noviembre de 1988; (B) vuelos de las 15:00 h para noviembre de 1988. (adaptado de Fuenzalida et al. 1989). ${ }^{1}$ 
TABLE 4

Published and unpublished Zeu-integrated Chl-a (B) and primary productivity (PP) data off Mejillones Peninsula (Antofagasta: $23^{\circ} \mathrm{S}$ ) and Punta Lengua de Vaca (Coquimbo: $30^{\circ} \mathrm{S}$ ) classified according to the season $(\mathrm{SU}=$ austral summer, WI $=$ austral winter, $\mathrm{SP}=$ austral spring), ENSO cycle ( $\mathrm{W}=$ warm or El Niño, $\mathrm{C}=$ cold or La Niña, $\mathrm{T}=$ transition), remote intraseasonal forcing (UP = rising sea-level, DO = decreasing sea-level, $\mathrm{ST}=$ stationary sealevel), and local, wind-driven upwelling forcing ( $\mathrm{AC}=$ active phase, $\mathrm{RX}=$ relaxed phase)

Datos publicados y no publicados de clorofila-a integrada en Zeu (B) y productividad primaria (PP) en la zona costera frente a la Península de Mejillones (Antofagasta, $23^{\circ} \mathrm{S}$ ) y Punta Lengua de Vaca $\left(\mathrm{Coquimbo}, 30^{\circ} \mathrm{S}\right.$ ), clasificados según la estación ( $\mathrm{SU}=$ verano austral, WI = invierno austral, $\mathrm{SP}=$ primavera austral), ciclo ENOS (W = cálido o El Niño, $\mathrm{C}=$ frío o La Niña, $\mathrm{T}=$ transición), forzamiento intraestacional remoto (UP = nivel del mar creciente, $\mathrm{DO}=$ nivel del mar decreciente, $\mathrm{ST}=$ nivel del mar estacionario) y forzamiento local de la surgencia debido al viento $(\mathrm{AC}=$ fase activa, $\mathrm{RX}=$ fase relajada $)$

\begin{tabular}{|c|c|c|c|c|c|c|c|c|c|c|c|}
\hline Season $^{1}$ & $\begin{array}{l}\text { ENSO } \\
\text { Cycle }^{2}\end{array}$ & Site & Year & Month & Day & Station & Zeu (m) & Ichla & PP & $\begin{array}{c}\text { For } \\
\text { Local }^{3}\end{array}$ & $\begin{array}{l}\text { cing } \\
\text { Remote }^{4}\end{array}$ \\
\hline SU & $\mathrm{T}$ & Antofagasta & 1997 & January & 24 & 15 & 62 & 19 & 2,234 & $\mathrm{AC}$ & ST \\
\hline SU & $\mathrm{T}$ & Antofagasta & 1997 & January & 29 & 15 & 17 & 175.4 & 4,771 & $\mathrm{AC}$ & ST \\
\hline SU & $\mathrm{T}$ & Antofagasta & 1997 & January & 30 & 15 & 13.5 & & 3,551 & $\mathrm{RX}$ & ST \\
\hline SU & $\mathrm{T}$ & Antofagasta & 1997 & January & 31 & 15 & 16.7 & & 5,053 & $\mathrm{RX}$ & ST \\
\hline WI & W & Antofagasta & 1997 & July & 9 & 15 & 62 & 22.5 & 338 & $\mathrm{RX}$ & UP \\
\hline WI & W & Antofagasta & 1997 & July & 10 & 15 & 65.7 & 17.5 & 981 & $\mathrm{RX}$ & UP \\
\hline WI & W & Antofagasta & 1997 & July & 22 & 15 & 34.3 & 36.8 & 1,823 & $\mathrm{RX}$ & UP \\
\hline SU & $\mathrm{T}$ & Antofagasta & 1997 & January & 22 & 1 & 48 & 110 & 6,063 & $\mathrm{RX}$ & DO \\
\hline SU & $\mathrm{T}$ & Antofagasta & 1997 & January & 20 & $24 \mathrm{~S}$ & 16 & 32 & 2,424 & $\mathrm{RX}$ & DO \\
\hline SU & $\mathrm{T}$ & Antofagasta & 1997 & January & 19 & $24 \mathrm{~S}$ & 14.4 & 40.8 & 1,474 & $\mathrm{RX}$ & DO \\
\hline SU & $\mathrm{T}$ & Antofagasta & 1997 & January & 15 & $27 \mathrm{~S}$ & 67.6 & 11.7 & 563 & $\mathrm{RX}$ & DO \\
\hline SU & $\mathrm{T}$ & Antofagasta & 1997 & January & 14 & $15 \mathrm{M}$ & 28 & 32.9 & 2,064 & $\mathrm{RX}$ & DO \\
\hline SU & $\mathrm{T}$ & Antofagasta & 1997 & January & 11 & $3 \mathrm{~N}$ & 74 & 13 & & $\mathrm{AC}$ & ST \\
\hline WI & W & Antofagasta & 1997 & July & 1 & $3 \mathrm{~N}$ & 57.5 & 16.4 & 620 & $\mathrm{AC}$ & UP \\
\hline WI & W & Antofagasta & 1997 & July & 2 & 15 & 41 & 32.9 & 370 & $\mathrm{AC}$ & UP \\
\hline WI & W & Antofagasta & 1997 & July & 4 & 27 & 54 & 31.1 & 2,045 & $\mathrm{RX}$ & UP \\
\hline WI & W & Antofagasta & 1997 & July & $11,12,13$ & Fmeji & 40.2 & 41.9 & 1,271 & $\mathrm{AC}$ & UP \\
\hline SU & W & Coquimbo & 1992 & April & 21 & 8 & 47.1 & 27.3 & 763 & $\mathrm{RX}$ & UP \\
\hline SU & W & Coquimbo & 1992 & April & 26 & 14 & 45 & 39 & 1,166 & $\mathrm{RX}$ & UP \\
\hline SU & W & Coquimbo & 1992 & April & 27 & 19 & 34 & 53 & 1,003 & $\mathrm{RX}$ & UP \\
\hline WI & W & Coquimbo & 1992 & June & 24 & 8 & 62 & 31.7 & 602 & $\mathrm{RX}$ & ST \\
\hline WI & W & Coquimbo & 1992 & June & 24 & 8 & 66 & 13.3 & 492 & $\mathrm{RX}$ & ST \\
\hline SP & $\mathrm{T}$ & Coquimbo & 1992 & October & 27 & 8 & & 14.3 & 140 & $\mathrm{AC}$ & ST \\
\hline SP & $\mathrm{T}$ & Coquimbo & 1993 & September & 25 & 8 & & 8 & 352 & $\mathrm{AC}$ & ST \\
\hline SU & $\mathrm{T}$ & Coquimbo & 1994 & January & 26 & 8 & 47.71 & 23 & 798 & $\mathrm{RX}$ & ST \\
\hline SU & $\mathrm{T}$ & Coquimbo & 1994 & January & 28 & 7 & 40.37 & 53.5 & 1,562 & $\mathrm{AC}$ & ST \\
\hline SU & $\mathrm{T}$ & Coquimbo & 1994 & January & 29 & 7 & 20.41 & 59.9 & 2,955 & $\mathrm{AC}$ & ST \\
\hline SU & $\mathrm{T}$ & Coquimbo & 1994 & January & 30 & 7 & 17.06 & 39.23 & 1,311 & $\mathrm{AC}$ & ST \\
\hline SU & $\mathrm{T}$ & Coquimbo & 1994 & January & 31 & 5 & 17.14 & 92.5 & 2,416 & $\mathrm{RX}$ & ST \\
\hline SU & $\mathrm{T}$ & Coquimbo & 1994 & February & 1 & Buoy & 21.319 & 66.5 & 1,166 & $\mathrm{RX}$ & ST \\
\hline SP & W & Coquimbo & 1994 & September & 28 & & & & & & \\
\hline SU & W & Coquimbo & 1995 & January & 24 & & & & & & \\
\hline SU & W & Coquimbo & 1995 & January & 29 & 8 & 50 & 28.45 & $1,194.1$ & $\mathrm{RX}$ & ST \\
\hline SU & W & Coquimbo & 1995 & January & 30 & 8 & 50 & 20.4 & $1,188.9$ & $\mathrm{AC}$ & ST \\
\hline SU & W & Coquimbo & 1995 & January & 31 & 8 & 59 & 9.44 & 1,105 & $\mathrm{AC}$ & ST \\
\hline WI & $\mathrm{T}$ & Coquimbo & 1995 & July & 9 & 8 & 84.2 & 8.22 & $1,011.9$ & $\mathrm{AC}$ & DO \\
\hline SU & $\mathrm{C}$ & Coquimbo & 1996 & January & 27 & 7 & 54 & & 1,589 & $\mathrm{AC}$ & UP \\
\hline SU & $\mathrm{C}$ & Coquimbo & 1996 & January & 30 & P1 & & & & $\mathrm{RX}$ & UP \\
\hline WI & $\mathrm{C}$ & Coquimbo & 1996 & July & 22 & $\mathrm{G} 2-22$ & & 43.06 & & $\mathrm{AC}$ & ST \\
\hline WI & $\mathrm{C}$ & Coquimbo & 1996 & July & 23 & G5-32 & 73 & 38.46 & & $\mathrm{AC}$ & ST \\
\hline WI & $\mathrm{C}$ & Coquimbo & 1996 & July & 24 & G6-36 & & 74.32 & & $\mathrm{AC}$ & ST \\
\hline SU & $\mathrm{T}$ & Coquimbo & 1997 & February & 6 & 42 & & & & $\mathrm{AC}$ & ST \\
\hline SU & $\mathrm{T}$ & Coquimbo & 1997 & February & 7 & 31 & 54.2 & 24.83 & 1,216 & $\mathrm{AC}$ & ST \\
\hline SU & $\mathrm{T}$ & Coquimbo & 1997 & February & 7 & 29 & 27.1 & 25.38 & 2,224 & $\mathrm{AC}$ & ST \\
\hline SU & $\mathrm{T}$ & Coquimbo & 1997 & February & 8 & 16 & 41.9 & 23 & $1,317.9$ & $\mathrm{AC}$ & ST \\
\hline SU & $\mathrm{T}$ & Coquimbo & 1997 & February & 8 & 6 & 70 & 37.2 & 700.5 & $\mathrm{AC}$ & ST \\
\hline SU & $\mathrm{T}$ & Coquimbo & 1997 & February & 10 & 8 & 58.6 & 45.8 & 1,474 & $\mathrm{AC}$ & ST \\
\hline SP & W & Coquimbo & 1997 & November & 4 & 8 & 82 & 37.25 & 623 & $\mathrm{AC}$ & ST \\
\hline SP & W & Coquimbo & 1997 & November & 5 & 8 & 82 & 23.78 & 1,444 & $\mathrm{AC}$ & ST \\
\hline
\end{tabular}

(1) $\mathrm{SU}=$ JFMA, WI = MJJA, SP = SOND; (2) $\mathrm{T}=$ transition, $\mathrm{W}=$ warm, $\mathrm{C}=$ cold ;

(3) $\mathrm{AC}=$ active, $\mathrm{RX}=$ relaxation; (4) $\mathrm{UP}=$ up, DO = down, $\mathrm{ST}=$ stationary 
TABLE 5

Comparison of "phytoplankton patterns" as the response of mean daily primary production in $\mathrm{mg} \mathrm{C} \mathrm{m}{ }^{-2} \mathrm{~d}^{-1}(\mathrm{PP})$ and Zeu-integrated Chl-a in $\mathrm{mg} \mathrm{m}^{-2}$ (B) over a full local forcing cycle between Cruz Grande bay (Table 3) and equivalent data in the other sites from Table 4.

Interannual, seasonal and intraseasonal conditions are respectively indicated. PP and B values are averaged from 2 to 5 stations and in 1 to 3 days

Comparación de los "patrones de fitoplancton" como la respuesta de la productividad primaria diaria promedio en mg C m ${ }^{-2} \mathrm{~d}^{-1}$ y la Cl-a integrada en Zeu en $\mathrm{mg} \mathrm{m}^{-2}$ (B) sobre un ciclo completo de forzamiento local entre Bahía Cruz

Grande (Tabla 3) y datos equivalentes de los otros lugares señalados en la Tabla 4. También se indican las respectivas condiciones interanuales, estacionales e intraestacionales. Los valores de PP y B son promedios de 2 a 5 estaciones en 1 a 3 días

\begin{tabular}{|c|c|c|c|c|c|c|c|c|c|}
\hline \multirow[t]{2}{*}{ Sites } & \multirow[t]{2}{*}{$\begin{array}{l}\text { ENSO } \\
\text { cycle }\end{array}$} & \multirow[t]{2}{*}{$\begin{array}{l}\text { Seasonal } \\
\text { cycle }\end{array}$} & \multirow{2}{*}{$\begin{array}{c}\text { Intra-seasonal } \\
\text { cycle } \\
\text { (sea-level) }\end{array}$} & \multicolumn{2}{|c|}{$\begin{array}{l}\text { Upwelling } \\
\text { active }\end{array}$} & \multicolumn{2}{|c|}{$\begin{array}{l}\text { Upwelling } \\
\text { relaxed }\end{array}$} & \multicolumn{2}{|c|}{$\begin{array}{l}\text { Phytoplankton } \\
\text { pattern }\end{array}$} \\
\hline & & & & $\mathrm{PP}$ & B & $\mathrm{PP}$ & B & $\mathrm{PP}$ & B \\
\hline $\begin{array}{l}\text { Cruz Grande bay } \\
\text { November } 1987\end{array}$ & Warm & Spring (+) & Rising & 620 & 28 & 439 & 107 & $\mathrm{PP}=>\downarrow \mathrm{PP}$ & $\mathrm{B} \Rightarrow \uparrow \uparrow \mathrm{B}$ \\
\hline $\begin{array}{l}\text { Cruz Grande bay } \\
\text { November } 1988\end{array}$ & Cold & Spring $(+)$ & Stationary & 222 & 36 & 622 & 56 & $\mathrm{PP} \Rightarrow \uparrow \uparrow \mathrm{PP}$ & $\mathrm{B} \Rightarrow \uparrow \mathrm{B}$ \\
\hline $\begin{array}{l}\text { Punta Lengua de Vaca } \\
\text { January } 1995\end{array}$ & Warm (-) & Summer (-) & Stationary & 1147 & 15 & 1194 & 28 & $\mathrm{PP}=>\leftrightarrow \mathrm{PP}$ & $B \Rightarrow \uparrow \uparrow B$ \\
\hline $\begin{array}{l}\text { Punta Lengua de Vaca } \\
\text { January } 1994\end{array}$ & Warm (-) & Summer (-) & Stationary & 1943 & 51 & 1791 & 79 & $\mathrm{PP}=>\leftrightarrow \mathrm{PP}$ & $\mathrm{B} \Rightarrow \uparrow \uparrow \mathrm{B}$ \\
\hline $\begin{array}{l}\text { Mejillones Peninsula } \\
\text { July } 1997\end{array}$ & Warm $(+)$ & Winter & Rising & 754 & 30 & 1297 & 27 & $\mathrm{PP} \Rightarrow \uparrow \uparrow \mathrm{PP}$ & $\mathrm{B} \Rightarrow \nrightarrow \leftrightarrow \mathrm{B}$ \\
\hline
\end{tabular}

(+) strong (ENSO)/seasonally late; (-) mild (ENSO)/seasonally early

$\uparrow \downarrow=$ small changes up/down; $\uparrow \uparrow=$ large changes up

$\leftrightarrow=$ no change

$\Rightarrow=$ transition from the active to the relaxed phase of the upwelling

condition leads to an enhanced presence of midlatitude disturbances in central Chile, producing more frequent and stronger UFWE's, particularly in austral winter. However during the November 1987 experiment the UFWE lasted for about 6 days from the onset of the active phase to the onset of relaxation, with a full cycle being completed in about 10 days. This period is longer than the climatological mean recurrence and might have corresponded to an intraseasonal maximum forced by the cold, rising sea-level conditions nearshore. On the other hand, the wind reversal (SW to NW) during the upwelling relaxation phase (Fig. 2) produced a rapid dissipation of the upwelling plume and the onshore advection and mixing with warm oceanic waters, leading to an increase in stratification (downwelling) and to the confinement of potentially productive waters close to the coast.

These environmental conditions promoted a rapid near-shore growth of the phytoplankton (B) and the decrease in PP, probably due to self-shading and other factors that will be discussed later.

The opposite extreme of the ENSO cycle in 1988 resulted in a stronger and poleward-displaced subtropical anticyclone. Under those con- ditions synoptic waves and associated frontal activity concentrated south of $41^{\circ} \mathrm{S}$ (Fig. 3B), with a high persistence of coastal cloudiness in northcentral Chile. These factors could possibly explain the relatively long period with mild southerlies, with only minor UFWE's in between.

The warmer oceanic waters, the deeper thermocline (Moraga, 1996) and the position of the upwelling front close to the coast are consistent features with the El Niño signal (i.e., Strub et al. 1998). The sharp cross-shore thermal contrast and more structured fields during the active upwelling phase in 1987 (warmer water closer to the coast) was presumably due to the rising sea-level phase (thermocline shoaling: nearshore colder water) of the intraseasonal cycle. The relatively warmer SST's next to the shoreline and the less structured fields in space and time observed in 1988 could be attributed to the reduced SST contrast with the colder oceanic waters characteristic of La Niña conditions. The steadiness of the intraseasonal signal in the ASL during the experiment and the solar warming in shallow waters associated with the weak mixing present during the extended wind-relaxation period, could have also contributed to the observed SST pattern. 
These environmental conditions promoted a moderate and positive change in $\mathrm{B}$ and a rapid increase in the carbon fixation rate, probably associated with widespread favorable conditions in which small and fast growing phytoplankton should dominate.

In general, after an upwelling event B increases while the phytoplankton shows an increment of chain-forming diatoms (i.e., the dominant species was Leptocylindrus danicus in 1987 and Skeletonema costatum in 1988). Therefore trends in the phyto-pattern ( $\mathrm{PP}$ and $\mathrm{B}$ responses) could be produced by differences in cell-size structure and succession patterns of the phytoplankton assemblages. Results from a study of the cell-size influence on the specific primary production off Punta Lengua de Vaca in January (warm season) and July (cold season) 1996 (La Niña), reveal that the small sizes dominate during the cold season, increasing the specific primary production (Montecino \& Quiróz 2000). These results are consistent with the cold phyto-pattern described here.

The dependency of the phytoplankton response to the intensity-duration (frequency) of the local forcing cycles can be understood in the frame of the physiological stages of the phytoplankton growth following the upwelling plume (Lagrangian approach) after the onset of upwelling. MacIsaac et al. (1985) have defined those stages in terms of nutrient concentration, light intensity and turbulence (mixing), for a typical 5 day-50 km time-space scales. This concept is especially relevant for the area off Punta Lengua de Vaca where winds and ocean currents are particularly energetic (i.e., Torres et al. 1999), implying that phytoplankton acclimation should be slow. Therefore, rapid and energetic upwelling cycles indicate that high phytoplankton growth rates can only proceed in protected bays (MacIsaac et al. 1985). Brown \& Field (1986) recognize that from newly upwelled waters to aged (nutrientdepleted) ones, the rate of primary production changes from low values (including small initial biomass), then increases sharply after the relaxation onset and then decreases again due to light limitations (self-shading), nutrient depletion and phytoplankton composition differences. Therefore, frequent upwelling means that the low-nutrient condition acting to decrease primary production rates is never attained, though the mean phytoplankton biomass of the area is reduced. In this context the phytoplankton production stages throughout the local upwelling forcing cycles seems to be more dependent on the frequencyintensity of those cycles than on the large-scale interannual ones (MacIsaac et al. 1985, Brown \& Field 1986, Service et al. 1998). In fact the warm
El Niño conditions seem to affect only the spatial distribution of the biological production, probably through the restriction of the productivity to a narrow band close to the coast (Wilkerson \& Dugdale 1987, Ulloa et al. 2001).

Consistent with the previous discussion, the biological response showed clearer patterns during 1987 when the range of the N/P values changed from 2 to 12 throughout the upwelling event (J. Olivares personal communication). In non-limiting nutrient conditions, the increase in phytoplankton Chl-a in 1987, associated with clear skies (Fig. 2) produced the decrease in Zeu, in the nutrient concentration and in $\mathrm{PB}_{\max }$ (Table 3 ). Since high $\mathrm{PB}_{\max }$ values indicate favorable physiological conditions of autotrophs (Harrison et al. 1981), the increase of the self-shading effect after the phytoplankton growth could be responsible of the lower $\mathrm{PB}_{\max }$ values in the coastal waters (onshore advection) after the upwelling event.

However in 1988, although Zeu increased and the phytoplankton decreased in the reversed forcing cycle sequence, $\mathrm{PB}_{\max }$ resulted independent of Zeu (Table 3). This is attributable to a light history with smoother changes, as well as to less significant variations in the nutrient concentration, with the exception of November 7 nearshore where no primary production measurements are available to see a possible departure from the general pattern. While mixing and upwelling bring together light and nutrients that are important for photosynthesis, deep vertical mixing reduces mean absorbed irradiance (Cullen \& Mc Intyre 1998).

From the available biological data analyzed here it may be tentatively concluded that, though all the scales of time variability seem to interact strongly in positioning the nutricline closer or farther from the euphotic zone, warm (El Niño, summer, sinking sea-level) conditions tend to favor an increase in B throughout the full cycle in the local upwelling forcing. Conversely, an increase in PP would be favored during cold (La Niña, winter, rising sea-level) conditions, without a significant increase in B. This schematic phyto-pattern should be further validated with more experimental data including full local upwelling forcing cycles and the continuos monitoring of the depth of the thermocline/nutricline.

Table 5 indicates that the ENSO "cold/warm" signal may be offset by more than one opposite thermal condition when all the time-scales of variability are simultaneously considered in defining the phyto-pattern associated with a particular cycle of the local upwelling forcing. However, clear-cut signals are not always to be expected, in particular during transition or neutral (i.e., stationary sea-level) periods. 
The significant linear correlation found between the depth of the euphotic layer and the surface Chl-a constitutes a useful contribution to the data base required for the retrieval of Chl-a from satellite-derived ocean color data off the Chilean coast, where studies on phytoplankton dynamics are scarce and space-limited (Montecino et al. 1998, Marín \& Olivares 1999, Thomas 1999, Daneri et al. 2000, Iriarte et al. 2000). The Chl-a concentrations and depths of the euphotic zone obtained here compare well with those reported for upwelling areas in Perú by Guillén \& Calienes (1981), in northern Chile by Morales et al. (1996) and Ulloa et al. (2001) and in the Benguela system by Brown \& Field (1986).

In summary, changes in the phytoplankton response (phyto-pattern) throughout a local upwelling forcing cycle have been addressed here in a zone where upwelling-favorable wind events (UFWE's) occur in a pulsating way throughout the year. This high-frequency variability (UFWE's) is modulated by low-frequency interannual (ENSO cycle), seasonal and intraseasonal (CTW's) scales of variability which set the stage for a given phyto-pattern to develop. These results imply a word of caution when interpreting primary production measurements without due account of the environmental variability in several relevant time scales.

\section{AKNOWLEDGEMENTS}

The participation of the Physical and Chemical Oceanography Group at the Universidad Católica del Norte, Coquimbo together with the Meteorology Group of the Universidad de Chile, were of particular relevance to the success of the 19871998 field program. Special thanks are due to Boris Garcia for phytoplankton analyses. We also wish to thank Julio Moraga, Jorge Olivares, Martin Farías and Gemita Pizarro for providing unpublished information, to the Chilean Navy Meteorological Service for providing Punta Tortuga data and to Ted Strub and the anonymous reviewers that significantly helped in the improvement of the manuscript. The sea-level data was kindly provided by Samuel Hormazábal. This study was partially supported by the Marine Sciences Development Program of the University of Chile and the "Camanchacas" Project. A revised version of a previous manuscript including the wind climatology and the multiscale comparison of new environmental and biological data has been supported by the FONDAP- Humboldt Program and by the Program on Atmospheric Dynamics and Climate (PRODAC), Universidad de Chile.

\section{LITERATURE CITED}

BEARDSLEY R, C DORMAN, A FRIEHE, K ROSENFELD \& C WINNANT (1987) Local atmospheric forcing during the Coastal Ocean Dynamics Experiment. I. A description of the marine boundary layer and atmospheric conditions over a northern California upwelling region. Journal of Geophysical Research 92: 1467-1488.

BROWN PC \& JG FIELD (1986) Factors limiting phytoplankton production in a near shore upwelling area. Journal of Plankton Research 8: 55-68.

CULLEN J \& JG MACINTYRE (1998) Behavior, physiology and the niche of depth-regulating phytoplankton. NATO ASI Series G 41: 559-579.

DANERI G, V DELLAROSSA, RA QUIÑONES, B JACOB, P MONTERO \& O ULLOA (2000) Primary production and community respiration in the Humboldt Current System off Chile and associated oceanic areas. Marine Ecology Progress Series 197: 41-49.

FONSECA T \& M FARÍAS (1987) Estudio del proceso de surgencia en la costa chilena utilizando percepción remota. Investigaciones Pesqueras (Chile) 34: 33-46

GONZÁLEZ HE, G DANERI, D FIGUEROA, J IRIARTE, N LEFÈVRE, G PIZARRO, R QUIÑONES, M SOBARZO \& A TRONCOSO (1998) Producción primaria y su destino en la trama trófica pelágica y océano profundo e intercambio océano-atmósfera de $\mathrm{CO}_{2}$ en la zona norte de la Corriente de Humboldt $\left(23^{\circ} \mathrm{S}\right)$ : posibles efectos del evento El Niño 1997. Revista Chilena de Historia Natural 71: 429-458.

GUILLÉN O \& R CALIENES (1981) Upwelling off Chimbote. In: Richards FA (ed) Coastal upwelling: 312-326. American Geophysical Union, Washington, District of Columbia.

HARRISON WG, T PLATT, R CALIENES \& N OCHOA (1981) Photosynthetic parameters and primary production of phytoplankton populations off the northern coast of Perú. In: Richards FA (ed) Coastal upwelling: 303-311. American Geophysical Union, Washington, District of Columbia.

HORMAZÁBAL S, G SHAFFER, J LETELIER \& O ULLOA (2001) Local and remote forcing of seasurface temperature in the coastal upwelling system off Chile. Journal of Geophysical Research 106: 16657-16671.

IRIARTE JL, G PIZARRO, VA TRONCOSO \& M SOBARZO (2000) Primary production and biomass of size-fractionated phytoplankton off Antofagasta, Chile (23-24요 $)$ during pre-El Niño and El Niño 1997. Journal of Marine System 26: 37-51.

KALNAY E, M KANAMITSU, R KISTLER, W COLLINS, D DEAVEN, L GANDIN, M IREDELL, S SAHA, G WHITE, J WOOLLEN, Y ZHU, M CHELLIAH, W EBISUZAKI, W HIGGINS, J JANOWIAK, KC MO, C ROPELEWSKI, J WANG, A LEETMA, R REYNOLDS, R JENNE \& D JOSEPH (1996) The NCEP/NCAR 40-year Reanalysis Project. Bulletin of the American Meteorological Society 77: 437-471.

KIRK JTO (1995) Light and photosynthesis in aquatic ecosystems. Second edition. Cambridge University Press, Cambridge, United Kingdom. 509 pp. 
MAC ISAAC JJ, RC DUGDALE, RT BARBER, D BLASCO \& TT PACKARD (1985) Primary production cycle in an upwelling center. Deep Sea Research 12: 503-529.

MARGALEF R \& F VIVES (1967) La vida suspendida en las aguas. Ecología Marina: 493-562. Monografía 14. Fundación La Salle de Ciencias Naturales, Caracas, Venezuela.

MARÍN V, L RODRÍGUEZ, L VALLEJO, J FUENTESECA \& E OYARCE (1993) Efectos de la surgencia costera sobre la productividad primaria primaveral de bahía Mejillones del Sur (Antofagasta, Chile). Revista Chilena de Historia Natural 66: 479491.

MARÍN V \& GR OLIVARES (1999) Estacionalidad de la productividad primaria en Bahía Mejillones del Sur (Chile): una aproximación proceso-funcional. Revista Chilena de Historia Natural 72: 629-641.

MONTECINO V \& G PIZARRO (1995) Phytoplankton acclimation and spectral penetration of UV irradiance off the central Chilean coast. Marine Ecology Progress Series 121: 261-269.

MONTECINO V, G PIZARRO \& D QUIRÓZ (1996) Dinámica fitoplanctónica en el sistema de surgencia frente a Coquimbo $\left(30^{\circ} \mathrm{S}\right)$ a través de la relación funcional entre fotosíntesis e irradianza (P - I). Gayana Oceanología (Chile) 4: 139-151.

MONTECINO V, G PIZARRO \& D QUIRÓZ (1998) Primary production in the Chilean coast. In: Holloway G \& D Henderson (eds) Proceedings of the Aha Huliko'a Hawaiian Winter Workshop of the University of Hawaii at Manoa: biotic impact of extratropical climate variability in the Pacific: 69-76. SOEST Special Publication, Honolulu, Hawaii.

MONTECINO V \& D QUIRÓZ (2000) Specific primary production and phytoplankton size structure in an upwelling area off the coast of Chile $\left(30^{\circ} \mathrm{S}\right)$. Aquatic Sciences 62: 364-380.

MORAGA J (1996) Capa límite marina en la zona costera frente a Chile en los $29,5^{\circ} \mathrm{S}$. Estudios Oceanológicos (Chile) 15: 17-28.

MORALES CE, JL BLANCO, M BRAUN, H REYES \& N SILVA (1996) Chlorophyll-a distribution and associated oceanographic conditions in the upwelling region of northern Chile during the winter spring 1993. Deep-Sea Research 43: 267-289.

PIZARRO G, JL IRIARTE \& V MONTECINO (2002) Mesoscale primary production and bio-optical variability off Antofagasta (23-24 $\mathrm{S}$ ) during the transition to El Niño 1997-1998. Revista Chilena de Historia Natural 75: 000-000.

RICHARDS FA (ed) (1981) Coastal upwelling. American Geophysical Union, Washington, District of Columbia. 529 pp.

RODRÍGUEZ L, V MARÍN, M FARÍAS \& E OYARCE (1991) Identification of an upwelling zone by remote sensing and in situ measurements. Mejillones del Sur Bay (Antofagasta-Chile). Scientia Marina 55: 467-473.

Associate Editor: R. Quiñones

Received September 22, 2000; accepted December 3, 2001
RUTLLANT J (1981) Subsidencia forzada sobre ladera andina occidental y su relación con un episodio de contaminación atmosférica en Santiago. Tralka 2: 57-76.

RUTLLANT J (1994) Modeling the day to day wind variability off central Chile at about $30^{\circ} \mathrm{S}$. International Centre for Theoretical Physics (Trieste-Italy). Internal Report IC/94/167. (available from the author)

RUTLLANT J \& H FUENZALIDA (1991) Synoptic aspects of the central Chile rainfall variability associated with the Southern Oscillation. International Journal of Climatology 11: 63-76.

RUTLLANT J, H FUENZALIDA, R TORRES \& D FIGUEROA (1998) Interacción océano-atmósferatierra en la región de Antofagasta (Chile 23 S): experimento DICLIMA. Revista Chilena de Historia Natural 71: 405-427.

SERVICE SK, JA RICE \& FP CHÁ VEZ (1998) Relationship between physical and biological variables during the upwelling period in Monterey. Deep-Sea Research 2: 1669-1685.

SHAFFER G, O PIZARRO, L DJURFELDT, S SALINAS \& J RUTLLANT (1997) Circulation and low frecuency variability near the Chile coast: remotely-forced fluctuations during the 1991-1992 El Niño. Journal of Physical Oceanography 27: 217-235.

SHINDLER DW (1966) A liquid scintillation method for measuring carbon-14 uptake in photosynthesis. Nature 211: 844-845.

STRICKLAND JDH \& TR PARSONS (1968) A practical handbook of seawater analysis. Fisheries Research Board of Canada Bulletin 167: 311.

STRUB P, JM MESÍAS, V MONTECINO, J RUTLLANT \& S SALINAS (1998) Coastal ocean circulation off western South America. In: Brink KH \& AR Robinson (eds) The global coastal ocean: the sea 11: 273-313. Wiley and Sons, Inc., New York, New York.

THOMAS AC (1999) Seasonal distribution of satellitemeasured phytoplankton pigment concentration along the Chilean coast. Journal of Geophysical Research 104: 25877-25890.

TORRES R, DR TURNER, N SILVA \& J RUTLLANT (1999) High short-term variability of $\mathrm{CO}_{2}$ fluxes during an upwelling event off the Chilean coast at $30^{\circ} \mathrm{S}$. Deep-Sea Research I 46: 1161-1179.

TRENBERTH KE (1997) The definition of El Niño. Bulletin of the American Meteorological Society 78: 2771-2777.

ULLOA O, R ESCRIBANO, S HORMAZÁBAL, RA QUIÑONES, RR GONZÁLEZ \& M RAMOS (2001) Evolution and biological effects of the 1997-98 El Niño in the upwelling ecosystem off northern Chile. Geophysical Research Letters 28: 1591-1594.

WILKERSON FP \& RC DUGDALE (1987) Effects of El Niño on new, regenerated, and total production in eastern boundary upwelling systems. Journal of Geophysical Research 92: 14347-14353.

YÁÑEZ E, A GONZÁLEZ \& MA BARBIERI (1995) Sea surface thermal structure associated to the space-temporal distribution of sardine and anchovy in northern Chile. Investigaciones Marinas (Chile) 23: 123-147. 